\title{
A neglected pool of labour? Frontline service work and hotel recruitment in Glasgow
}

Sharon Bolton, University of Stirling

Knut Laaser, University of Stirling

Darren McGuire, University of Stirling

This is the peer reviewed version of the following article: Bolton, S. C., Laaser, K., McGuire, D., and Duncan, A. ( 2019) A neglected pool of labour? Frontline service work and hotel recruitment in Glasgow. European Management Review, 16: 567-578, which has been published in final form at https://doi.org/10.1111/emre.12172. This article may be used for noncommercial purposes in accordance with Wiley Terms and Conditions for self-archiving.

Accepted for publication in European Management Review published by Wiley. 


\begin{abstract}
The article presented considers soft skills in the hospitality sector and explores how managers in four hotels in Glasgow, Scotland enact recruitment and selection processes. Empirically, the analysis is based on a rich cross case comparison including interviews, observations, attendance at training events and analysis of hotels' recruitment and selection policies. Conceptually, the analysis draws on the work of Pierre Bourdieu and Andrew Sayer, portraying an understanding of social class as a social, economic, and cultural category and people's agency as shaped by their habitus and lay normativity. Crucially, the paper reveals the pivotal role individual managers play in enabling and constraining opportunities for employment in the enactment of hotel recruitment policy and engagement with job applicants and new recruits. Overall, the analysis suggests that, despite many deterministic analyses of class, an organisation's recruitment, learning and development strategies, plus management's commitment to make a difference, can positively impact on those who might otherwise be part of a neglected pool of labour.
\end{abstract}




\section{Introduction}

Over the last two decades, the heterogeneous service industry has become a driving force of the EU economy, being responsible for a significant proportion of the overall growth in productivity and employment. The hospitality sector is particularly significant, accounting for 17\% of net employment growth in the UK between 2010 and 2014 (Oxford Economics, 2015). Despite its growing importance as a major European employer, the sector reports that a significant proportion of job seekers lack essential service skills vital in hospitality jobs (Cedefop, 2015; UKCES, 2014; European Commission, 2015). It is well documented that the hospitality industry is non-strategic in its approach to recruitment and selection (Lockyer and Scholarios, 2004; Nickson, 2013), and yet research focussing on the role that management plays in alleviating or exacerbating the so called 'soft skills gap' remains scarce (see Hurrell, 2016).

The 'soft skills gap' has led to vibrant discussion concerning the nature of skill; questioning whether soft skills that feed into effective customer service are innate or can be developed; asking who might possess such skills and whether they are skills at all (Bolton, 2004; Bryson, 2017; Grugulis et al., 2004; Hampson and Junor, 2010; Hurrell et al., 2013; Nickson et al, 2012). Whilst the notion of skills is contested and may be seen as a 'blunt instrument', it opens up lines of inquiry that may not otherwise emerge quite so clearly (Buchanen et al, 2017). For example, in what is described as a 'gentrification' of skill, interactional and aesthetic qualities, essential for customer service, are identified as middleclass attributes, cultivated through a lifetime's training of the presentation of self (Bolton, 2004; Nickson et al, 20012; Warhurst and Nickson, 2007). It has been argued that 'middleclassness' is inherent in an understanding of soft skills (Nickson et al, 2012:79; MacDonald and Merril, 2009), meaning the long term unemployed or those who embody poverty remain excluded from the labour market (Gatta, 2011; Standing, 2014). 
Drawing on empirical case studies of four major international hotels in Glasgow, this article explores the demand for soft skills in frontline hospitality sector jobs; considering how soft skills are conceptualised in line with company recruitment, selection and branding. In particular, we consider whether the observed recruitment and selection processes offer opportunities for social mobility for those from working class backgrounds and the role managers play in furthering or restricting opportunities. The analysis is informed by a theoretical lens that introduces Pierre Bourdieu's and Andrew Sayer's work on class, habitus and agency to the critical study of management. We argue that the application of Bourdieu's and Sayer's work is particularly useful for illuminating the relationship between class and organisational practices. The analytical frame combines a focus on the nature of the social, economic and cultural conditions that shape management's perceptions of the 'ideal' frontline service worker, whilst emphasising managers' capacities to reflect and evaluate structuring factors and commit to alternative views and practices. In revealing the pivotal role individual managers play in enabling and constraining opportunities for employment in the enactment of hotel recruitment policy, we suggest that despite many over-deterministic analyses of class, an organisation's recruitment, learning and development strategies, plus management's commitment to make a difference, can positively impact upon people who might otherwise be part of a neglected pool of labour.

\section{Recruiting the ideal front line service worker}

A dominant view in service work research is that soft skills are significantly different to technical skills, as they are considered to be intangible, innate and intertwined with individual traits such as personality, attitude and behaviour (Gatta, 2011; Korczynski, 2005). Whilst the debate on what counts as soft skills, and whether soft skills are indeed 'skills' marches on, employers consider abilities in team work, self-presentation and customer relationship 
building as essential for frontline service workers (Hurrell, 2016; Vincent, 2011). In a similar vein it has been argued that employing people with desirable soft skills or embodied 'dispositions' (Bourdieu, 1984), such as language, dress code, manner, style, shape and size of the body, are significant in achieving excellent customer service (Eustace, 2012; Macdonald and Merrill, 2009; McDowell, 2009). This is considered to be a particularly important feature in the hospitality sector, where workers are a part of the company brand and customer engagement with frontline service workers is often over a prolonged interlude (De Roeck et al. 2013; Nickson, 2013; Sherman, 2007).

Despite the consensus regarding the importance of recruiting employees with refined customer service skills into the hospitality sector, there is little research focused on the role that management plays in alleviating or exacerbating the 'soft skills gap' (Hurrell, 2016; Nieves, 2016). There are, however, two areas of management practice identified as contributing factors: first, the level of systematic training at an organisational level to enhance hospitality workers' soft skills is often lacking, as employers expect service workers to possess desired characteristics a priori (Baum, 2002; Korczysnki, 2005). Yet, as assessments of soft skills cannot be objectively measured and evaluated via standardized tests or educational certificates, assessments of candidates in terms of their soft skills remains subjective and open to individual interpretation (Moss and Tilly, 1996; Wolkowitz, 2006). Second, a body of research that focusses on the flourishing hospitality industry points towards an unsystematic, arm's-length management style and provides evidence that recruitment and selection practices in UK hotels are characterised by ad-hoc and informal decision-making (Knox and Walsh, 2005; Hurrell and Scholarios, 2014; Lockyer and Scholarios, 2004; Nickson, 2013). For example, informal recruitment methods such as wordof-mouth and introduce-a-friend act as gatekeepers to the industry, as people recruit in their own class-dependent image with similar experience, attitude, appearance and voice 
(McDowell, et al., 2007; Sozen et al. 2015). Thus, the 'blink' moment method of recruitment continues; ensuring that existing prejudices and stereotypical judgements regarding people's capacities remain entrenched (Gatta, 2011; Nickson et al, 2005). Among sorting mechanisms, managers in the hospitality sector funnel workers into positions based on 'typifications' of race, gender and class. Thus, it is through such means that class becomes a deciding factor over employees' life chances with front-line managers' enactment of recruitment and selection policy playing a key role. Yet evidence is scant regarding the dynamics behind the continued co-existence of high unemployment and staff shortages, which are particularly prevalent in the hotel sector in the UK. The article contributes to this field of literature by exploring the underlying organisational, social and economic mechanisms of recruitment practices in the Hotel industry in Glasgow and the role that management plays in alleviating or exacerbating the 'soft skills gap'.

\section{The dynamics of social class, habitus and agency}

The issue of conceptualising social class is a long and contentious one within the social sciences. Born of a language around meritocracy and equality of opportunity, the individualisation of risk and changing occupational categories, class is seen by some as no longer a useful means of understanding society (Beck, 1992; Pakulski and Waters 1996). Despite attempts to dismiss class as an analytical tool, conceptual and empirical inquiries into how class is constituted, how it operates and changes through occupational structures or social mobility continue to shape contemporary debates (Gallie et al., 2016; Goldthorpe and Mills, 2008; McGovern et al., 2007; Savage et al., 2013; Skeggs, 2004). Indeed, over the last three decades, conceptions of class go beyond the analytical categories of 'ownership or nonownership of means of production' (Sayer, 1995, p. 48-9) and the social division of labour now incorporating wider social and cultural dynamics (Lamont, 2000; Savage et al., 2013; 
Sayer, 2005; Skeggs, 2004). A testimony to this development is the popularity of Bourdieu's concepts of class and habitus that are widely utilised in economic and cultural sociology and are emerging in management and organisational studies (Gomez, 2010; Karatas s-Özkan and Chell, 2015; Ozbilgin and Tatli, 2005). In order to unravel the underlying structures of people's position in society and life-chances and experiences, Bourdieu (1984) developed a class concept that rests on the distinction of and interplay between three forms of capital: material wealth (economic capital), possession of cultural and institutionalised goods such as educational qualifications and internalized cultural expertise (cultural capital), and quality and quantity of social relationships and wider networks (social capital). Bourdieu's work emphasises that economic capital enables or constrains access to sources of social and cultural capital. The accumulation of social and cultural capital, in particular, relies on people's position in a social field that informs their socialisation into and internalization of dominant practices, valuations and judgements which requires a lengthy process of 'social osmosis, embodiment, learning (...)' (Sayer, 2005:78; Bourdieu, 1984). In this way, Bourdieu's thesis highlights that thanks to the durability of the different forms of capital, inequalities are characterized by path-dependency.

The path-dependency of inequalities is at the heart of Bourdieu's concept of habitus, which suggests that dispositions, skills, concerns and interests are developed through the experience of living in and becoming attuned to the prevailing material, social and cultural conditions of and practices within the social field in which people are situated. Linking individual actions and the macro-structural setting, the habitus represents a 'structuring structure' (Bourdieu, 1984) that features a 'durable manner of standing, speaking and thereby of feeling and thinking' (Bourdieu, 1977:93). The structure of these dispositions organize people's actions, life-styles and perceptions; their 'feel for the game' and sense of entitlement to positions and practices within their social field. In turn, the habitus enforces 
sharp distinctions between groups thanks to its quality of a structured structure (Bourdieu, 1984) that is informed 'by oppositions related by homologies among disparate phenomena' (Sayer, 2005:24). Therein, people who are privileged in terms of social, cultural and economic capital tend to classify and (de)value the actions, aesthetics and demeanour of the less privileged as inappropriate for practices and relationships within their social field. In turn, people from less privileged classes become attuned to their social field and develop dispositions that accept their domination and develop ways to cope with it.

Whilst Bourdieu's approach offers a rich opportunity for understanding the nature of the structural conditions that create 'homogenous conditioning' (Bourdieu, 1984:101), it has been subject to critique for its over emphasis on unconscious workings of the habitus that promotes a deterministic understanding of human capacity to effect change (Archer, 2007; Emirbayer and Mische, 1998; Mouzelis, 1995; Sayer, 2005, 2011). Andrew Sayer's seminal works on critical social science $(2011 ; 2009)$ and the moral dimensions of class (2005) offer a way to utilise Bourdieu's multi-layered concept of capital and habitus whilst maintaining a strong notion of agency. Sayer acknowledges the power of the social, material and economic conditions and the habitus for structuring people's actions, experiences and life-chances (Sayer, 2005). Yet, Sayer also places an emphasis on people's reflective and evaluative capacities that stem from developed and innate needs, concerns, and capacities they possess as beings who are capable of connecting, flourishing and suffering (Sayer, 2011). He argues that the habitus is developed not only through the unconscious process of internalizing dominant practices and ways of being, but is also linked to people's needs and concerns that inform deliberations over the activation of particular dispositions in social fields and how they impact on their own and others' well-being (Sayer, 2010). The approach suggests that whilst many actions and categorisations operate at a semi-conscious level via internalized dispositions, people may question taken for granted assumptions if they are exposed to 
experiences and relationships that disrupt them, or if their needs and concerns change due to activities in different social fields.

Sayer, however, does not suggest that the different forms of class and habitus are flexible and easily mediated. Rather, it is argued that people have the capacity to behave outside expected norms and learn ways of being not traditionally linked to their habitus thanks to an ability to reflect and reason about their place in the world (Sayer, 2011). Sayer suggests that people can change their habitus 'deliberately, at least in part, by repeated practice aimed at the embodiment of new dispositions' (Sayer, 2005:30). Sayer's critical revision of Bourdieu's concept of class and habitus renders socio-economic positioning and assignment to social class as structured and structuring powers because people hold an ability to mediate dominating dispositions. Thus, it is emphasized that if a habitus is learned, then it can equally be unlearned over-time if relational and structural enablers are available allowing people to change their material conditions so that new learning can take place (Archer, 2007; Sayer, 2011). The combination of Bourdieu's different forms of capital and Sayer's revision of habitus provides a rich concept for exploring the underlying social mechanisms of recruitment in the service sector and employers' perceptions of the 'ideal' frontline worker. In particular, it reveals how the construction of soft skills in tandem with potentially exclusionary recruitment practices are shaped and reshaped by the dynamics of social class, habitus and people's reflective capacities. Against this backdrop, drawing on Bourdieu and Sayer's seminal work, the article explores recruitment and selection in four major hotels and the actions and attitudes of hotel managers as labour market actors who, along with potential employees, are situated within the complex, often hidden, mechanisms of social class. 


\section{Research context and methodology}

Throughout the 20th century, Glasgow has confronted industrial change and social deprivation; experiencing a cycle of decline, renewal and regeneration. As an ex-industrial hub, the city is refocusing investment strategies to fit a service based economy and a new identity as a 'style city', where frontline service sector roles fulfill a significant proportion of total jobs in the labour market (Skills Development Scotland, 2016). As Scotland's largest urban economy, the city supports over 450,000 jobs and employs around 30,000 people in tourism and related industries (Grant, 2013). However, the nationally representative Employer's Skill survey shows that $24 \%$ of Hotel and Restaurant management report customer service skill gaps and difficulties in recruiting to frontline service roles (UK Commission for Employment and Skills, 2016). Similarly, UK service sector employers report that a significant proportion of job seekers, as well as employees, lack essential service skills (Hurrel, 2016; UKCES, 2014). Therein, the hotel industry in Glasgow represents an interesting case for exploring the underlying organisational, social and economic mechanisms of recruitment practices and management's role in alleviating or exacerbating the 'soft skills gap.'

The analysis presented is drawn from qualitative case studies of four large hotels in Glasgow. Fieldwork began with a study of two hotels, Skye and Barra. The Skye hotel is a 4* full service, upper-midscale American chain and well known in the timeshare and corporate accommodation markets. It is the recipient of several awards related to diversity and good employment practice. Skye has formal, traditional branding which is represented in the decor of the hotel and the staff uniforms. The Barra hotel is $5^{*}$ graded and was established in 1960 as a designer hotel. The branding is luxury with distinctive architecture, chic furniture and less formally dressed staff. The hotel prides itself on winning awards, including for the design of the building and excellent service. Yet findings from the two hotels displayed 
radically different approaches regarding managers' agency in the recruitment and selection process and the role class and habitus play in it. In order to explore these differences within a wider data sample the study was extended to include the Mull and the Islay hotels. Both hotels are based in Glasgow, have the same quality category, and are comparable in size, numbers of staff and focus on mid-to-upper ends of the market. The Mull hotel is a $4^{*}$ establishment in Glasgow city centre. It hosts a mixed market of corporate, leisure, conference and events guests and aims to fit with the larger group's aim of being part of an 'inspirational hotel collection'. The branding and traditionally formal dress of employees reflects the classical grandeur of the premises; the building has an elegant foyer, large staircase and an imposing chandelier. Whereas, the Islay hotel, also part of a major international operator in the $4-5^{*}$ travel market, places emphasis on international brand expectations, reflected in the approach to employee uniforms and formalised customer service.

Table one provides an overview of recruitment and selection in each hotel and features differences in the employment context and approach of each based on information derived from company documents, media coverage and interviews with managers.

\section{INSERT TABLE ONE HERE}

A qualitative research design was employed featuring semi-structured interviews, collection and analysis of official business strategy and employment policy documents of each hotel, and participant observation. In order to understand how employees are positioned and presented in the hotels, direct observation was conducted at seven different observational episodes, including attendance at staff induction events and time spent in the lobby and reception areas of all hotels. Overall, a total of twenty-eight hours of direct observation was recorded. Observational data was used as a scoping mechanism and a design aid for the semistructured interviews. The research team did not impose the conceptual grid of class and 
habitus upon interviewees by posing direct questions concerning the importance of social, economic and cultural capital of candidates for the recruitment and selection process. Rather, interview questions were guided by the interest in the recruitment and selection process and open-ended in nature, enabling interviewees to elaborate on experiences and situations in the recruitment and selection process, but also their daily work.

In total thirty-one interviews were conducted with management grade employees across the four hotels, each lasting between thirty to one hundred minutes. The analysis of the empirical material rests on several cycles of analysis that included thematic manual coding and a categorisation of themes in 'first-order' and 'higher-order' codes, using a qualitative data analysis program. Thematic analysis was conducted to identify recurring themes in interviews and observational notes (Braun and Clarke, 2006). Based on this process, higher order codes were created to group and label emerging themes within the interviews (for example 'centrality of cultural and social capital for the $\mathrm{R}$ and $\mathrm{S}$ process'; 'role of management in the $\mathrm{R}$ and $\mathrm{S}$ process'), that were, as part of the data analysis, grouped into lower-order codes (for example, the higher order code 'centrality of cultural and social capital for the $\mathrm{R}$ and $\mathrm{S}$ process' was grouped into more nuanced categories, as 'determining factor for R and S decisions' or 'mediates R and S decision' etc.). The lower-order codes then informed second order codes that drew on the different responses and sub-themes that emerged from the respondents across all four hotels.

The sample of managers cover different functional areas, including HR managers and/ or coordinators, plus those who line manage service employees, i.e. reception, bar and restaurant, housekeeping, and general duty managers. In line with large hotel chains, recruitment and practice functions and decisions are mainly devolved to line managers with the support of a hotel based HR partner (Maxwell and Watson, 2007). The managers encountered represent a predominantly Scottish group, though two Islay managers are from 
America and Australia, with a fairly balanced gender and educational mix. The sample is a combination of people who have entered the hotels as graduate trainees and those who worked up the hierarchy from frontline service positions. The majority of managers at Barra and Islay are graduates. Some were recruited as graduate trainees; others worked for Barra and Islay as students and took junior management trainee positions upon graduation. At Skye and Mull the majority of managers have worked their way through the hierarchy, from frontline service positions within the hotel into their current position. The data section below explores each hotel's approach to recruitment, selection, the underlying dynamics that shape the process, alongside management's perception of soft skills and the 'ideal' employee in frontline service work.

\section{Recruitment, selection and the 'ideal' employee at Barra, Skye, Mull and Islay} Skye

Evidence from Skye suggests the 'classic trio' (Nickson et al., 2012) of Advertising, Application/Screening and Interviewing are adopted in the recruitment process. Their HR manager refers to advertising on the hotel's website or in 'The Caterer' (an industry specific magazine) to target those who have a desire to work in the hospitality industry. Line managers however, place a heavier emphasis on referral of friends, but both are open about aiming to recruit employees who possess similar social and cultural capital and therefore 'fit' the team. In the process of selection in Skye, interviewing procedures are based on an objective situation/scenario test. Reflecting on the process a manager suggests,

'It's a situation, task, action and result scenario... It's all very corporate but what it does is ensure that when you ask someone a question, they don't just waffle at you' $(\mathrm{S} 1)$. 
In this context, the managers suggest candidates should be 'well-presented' because 'you can see they've made an effort (S1); which is believed to reveal a new recruit's potential 'work ethic' (S9). Nevertheless, whilst there is a veneer of formality (Price, 1993) embedded in the recruitment processes of Skye, management focuses strongly on informal interaction to judge the interpersonal skills and aptitude of employees.

'We've got loads of staff in here who've got no qualifications whatsoever but they know how to stick your breakfast down in front of you and say 'how you doing? How did you get on last night? You were telling me...' you have to have that sort of personality if you want to deal with people' (S6).

Managers in Skye consistently refer to the desire for customer service skills with the need for 'bubbly people who are friendly and willing to talk to guests' (S4), who 'have manners and the right attitude' (S7). Similarly, the managers describe the need for employees to have a pleasing oral aesthetic because of front stage activities being in close proximity to guests; they require a 'well-spoken' (S8) workforce that can 'express themselves' (S4) and are understood by the different nationalities who occupy the hotel (S5). Of note is that the relatively strong Scottish and Glaswegian accent is not deemed a 'big issue' (S6) in Skye; albeit, as long as employees adapt their accents in ways ensuring they are able to 'speak formally' (S2) 'in a legible and clear way' (S1), avoiding 'street talk' in public areas (S2).

Skye managers also articulate the desire for a well-groomed, presentable workforce, following company policy because 'How they're groomed matters... you can't pick all the pretty ones I'm afraid' (S3). With an aversion to fashion, Skye's 'New Employee Induction Pack' includes an in-depth six-page 'Grooming and Presentation' guidance booklet, aiming to refine corporate image through employee dress code. Attendance at induction training at Skye confirmed the rigorous detail managers enter into when discussing appearance so that new recruits are left in little doubt what the expectations are. This approach is linked to 
Skye's decision to recruit from demographic groups with limited formal and, particularly, higher and further educational experience and is viewed as an opportunity rather than control mechanism:

'We believe in recruiting local people. I think this generates stronger loyalty to the company. I came here when I was just a wee girl. To be honest, it's more work for us in training etc. But it's worth the investment as we get good employees and they get the opportunity to enter a different world (S6).

Barra

Barra, comparatively, places greater emphasis on recruiting new staff via the personal networks of current employees who are primarily university students: 'For me, it's mostly students or friends of friends who we interview' (B2). Various line managers suggest Barra does not need to advertise to fill frontline vacancies as 'people usually come in with their CV' (B3) and 'often we're given CVs from friends of employees who are already here' (B8):

'Obviously if you're recruiting from inside you've got a slight advantage as you always know if they are a nice person and if they're going to work for you' (B3).

All Barra managers suggest that fulfilling vacancies internally is preferential as it is assumed that recruiting staff from the same social group creates an inclusive culture that positively affects the provision of high quality service.

'We try to build an atmosphere here... of a kind of-not family... but more of friends and I think that our staff see that in the managers, then it bleeds through...you get the best out of people that way' (B3).

Observations confirm this view as staff and management interact continuously in a warm and convivial manner and frontline service workers display a casual confidence in exchanges 
with customers. The theme of informality feeds through the interviewing process with managers from Barra who refer to the recruitment and selection of new staff as 'a relaxed process' (B4, B7).

Frontline service work in Barra is in keeping with the non-traditional, friendly, contemporary service they aim to offer (B2, B4, B5, B6, B9). Reflecting on this, a manager suggests that customers are 'here for a waiter that's able to give a bit of chat... you know, break the ice and give a bit of banter' (B3). What is striking about the interviews with the Barra managers is the assertion that in order to offer a friendly service, the employee needs to position themselves on the 'same level' as guests. Despite the appearance of informality and equal status, there are high expectations placed upon frontline employees to bear the mark of a 'relaxed and confident' (B9) interactional approach, as represented in the interview question posed by a Barra manager:

'My favourite question is: 'tell me about your favourite dining experience' and some people will tell you about a time when they were at Weatherspoons [a value highstreet pub and restaurant chain], whereas other people would say they went to Brian Maules [a fine dining restaurant] or something like that, so you can gauge whether they actually like the industry that they are applying for. If they tell me they went to McDonalds and had a burger or a happy meal, I'll maybe be put back a little bit from my choice' (B2).

Barra's policy for grooming and appearance is flexible and individual. Upon entering the foyer of the hotel, the doorman wears a kilt and dark boots usually worn by workers in heavier industries. Employees are instructed to 'take pride in the way you look' (B2) but there is a freedom to represent individuality. The importance of individuality in the Barra case is illuminated by comments such as: 
'You can have any hairstyle... if it's long all we ask is that it's tied up during service.

When it comes to necklaces you can wear them. I don't have a problem with that' (B3).

Indeed, Barra managers are clear that they seek 'quirky' personalities (B2) or the 'cheeky chap' (B8). Despite this emphasis, local dialect can be seen as problematic, as a manager suggests, 'With somebody with a broad Glaswegian accent, you can't really understand a word they're saying... that would be a no' (B8). Hence, potential and existing employees are asked by managers to regulate their voice in frontline service environments and even in contexts where primary roles are not customer facing.

Mull

Recruitment and selection in Mull is driven by the aim to be the best conference, training and events-led group in Europe. They use a variety of means to advertise positions including word-of-mouth, industry magazines like The Caterer, online job forums and the Jobcentre. For the majority of frontline service workers, the recruitment process is particularly informal. Reflecting on the process, an HR manager notes how she actively 'speaks to people we know in the industry to see if there is maybe someone looking for a move' (M1). The selection process is equally informal:

'They'd probably sit with me for about fifteen to twenty minutes so I can get to know them and ask a couple of questions and see what their personalities are like' (M1).

Mull recruits a large number of students from a local college. They emphasise the importance of 'looking for very personable sorts of skills' (M3) so that its aim of delivering 'sensational services' is achieved. The focus is on seeking people who are able to 'quickly embed one's self in teamwork and be responsive to guests' needs' (M3).

A representative view of the group of managers from Mull, is that: 
'It comes down to your personality and your versatility and how you can deal with different types of people, really; that's throughout the hotel, but certainly for front of house, anyway. From my point of view, that's kind of what I'm looking for. I've always said that you can train technical stuff, but you can't train attitude' (M4).

The hotel's human resource manager is clear in her distinction between technical and soft skills:

'I could have someone on a CV that has fabulous, wonderful technical skill and then you speak to them and you interact with them and you ask them about our customers and what they imagine excellent customer service to be and they're maybe quite reserved and not overly customer friendly. So what do you do in that situation? Hire character, train skill!' (M2)

When probed about the soft skills that are particularly important, smiling, an accepting and open attitude, and high-level communication are discussed as vital ingredients in the soft skills mix. Whilst it is intuitive for the hotel to assess whether new recruits are blessed with inherent soft skills, it is difficult to ensure all new employees meet such high standards. For example, in one particularly illuminating conversation a manager articulated that the Glasgow accent could be problematic, even though many guests enjoyed it. Speaking about a female front desk colleague, he suggests

'I'm not being disrespectful to the girl but other people perceived her to be quite common. And that was just purely because of the way she spoke. She just spoke with quite a thick Glasgow accent and was kind of, just herself. People on the property, some people didn't like it and they thought she wasn't right. But I observed what happened and I used to see a lot of customers come in and she was just herself with the customers and gave all that Glasgow banter sort of thing. The customers loved it' (M5). 
This positivity led to an element of risk taking in the recruitment and selection process.

'If I felt that they had a fabulous personable manner about them I would take a calculated risk on that person and say, 'Do you know what? You're going to be great. We're going to give you the skills to do this job. You're going to be fabulous at it. Let's take a risk on you' (M6).

'Risk taking' in the selection process is also inherent within the Hotel's commitment to training and development. New employees are buddied with an experienced employee in an effort to build a professional support network in the organisation.

Mull's policy for grooming and appearance, encourages company standards of 'not too much jewellery, not too much makeup', and whilst managers voice a relaxed approach to employees' mode of dress, there is an emphasis on complying with the formal branding of the hotel. This is evidenced by a comment from a manager: 'our own company standards, as long as they're following them, absolutely fine' (M1).

Islay

The Islay hotel group aims to be the world's preeminent global hospitality company. Positions are advertised in local universities and recruitment websites including the caterer.com. Nevertheless, a majority of managers describe a preference for referrals from existing staff due to the emphasis on teamwork and a relaxed and confident interactional style. The banqueting manager is clear about the qualities he seeks in frontline staff:

'Someone who can make conversation, someone who is outgoing, someone who is maybe not too shy, because obviously if you're going to go up to a table of 10 or 12 people, you've got to have quite a bit of self-confidence to be able to just talk to people and, you know, especially on things like party nights or weddings, where 
people have had a couple of drinks, and you know, they might get a little bit cheeky ... and either just kind of go with it, or just give them something a little bit smart, say something back. Nothing rude or anything like that, just to get a laugh out of people' (I6).

Group interviews are used in the selection process at Islay. Some managers believe they are a way to make informed judgements regarding candidates' personality and aptitude.

'It is a challenge when you have ten people all competing at the same time for a job, but it also brings out the best in people. I like people that ask a lot of questions. You know that shows that they're willing to learn, and they have an interest in it to begin with. If somebody tends to sit quietly, you kind of wonder about ... how much input you're going to get from them' (I5).

Whether as an individual or group, the interview questions are competency based and focus on quality, productivity, adaptability, teamwork, customer focus and dependability; a corporate strategy espoused across the majority of the Islay interviews.

The Islay managers seek candidates that see the opportunity as a pathway to a career in the industry; who 'live and breathe hospitality' (I6). Furthermore, a leitmotif in the interviews is 'It's not about them having the skills - it's about the right attitude' (I6). According to a senior manager (I7), the hotel places emphasis on training and empowering employees. Every major department has a dedicated trainer and each new employee is expected to participate in a full induction process that includes brand orientation, operations, and health and safety. For front-line employees wishing to progress to supervisory or managerial levels, or for graduate recruits, the group offers over 7000 courses through its self-styled 'hotel university'. 
Islay managers suggest that local dialects do not present barriers to employment opportunities as long as interviewees do not use too much 'slang' (I3). Whilst the hotel is 'always looking for the candidate that's going to be well spoken and a well-rounded individual' (I6), and in terms of appearance, appreciate people who dress smartly, appropriately and neatly, who are 'always smiley (...) always, you know, nicely looking, like, uniform and stuff', they recognise that 'not everybody's like that' (I6).

\section{Discussion}

Drawing on empirical case studies of four international hotels in Glasgow and an understanding of class as a social, economic and cultural category, this article explores how customer service skills are conceptualised in the context of company strategy and branding; it considers the recruitment and selection processes and how they are enacted by managers in the context of the paradoxical co-existence of ample labour supply and professed recruitment difficulties. There are complex dynamics at play in the four hotels in terms of different approaches to service vision, formality/ informality in the enactment of recruitment and selection policies, varied degrees of involvement of line managers in the process and the cyclical impacts of previous recruitment and selection choices.

The hotels display a strong commonality in their emphasis on recruiting for attitude rather than technical skill. Indeed, the emphasis on a confident, relaxed interactional style makes unquestioned assumptions about how people should and do interact with others. For example, Barra's wish for staff to be socially 'on the same level' as guests, Islay's use of group interviews in order to identify interactional confidence, Mull's focus on recruiting for 'character', and Skye's desire to recruit well spoken, bubbly people. The way all the hotels talk of a good fit with, or quickly embedding into the existing team signifies that their ideal 
employee possesses homogenous dispositions that are derived from similar forms of social, economic and cultural capital (Bourdieu, 1977). This is, for example, encoded in the question posed by Barra management to candidates, in the selection process, about the type of restaurant they prefer. An approach that rests on the expectation that employees from a privileged background embody demeanors that guarantee a feel for the game and supports the hotel's promise of a fine dining experience. In a similar vein, Islay's preference for wellrounded, well-spoken individuals informs their focus on University graduates, assuming that this group can relate to and appease demanding customers thanks to their socialisation into social, economic and cultural conditions that have provided them with similar experiences (Sayer, 2005). The managers' view of an 'ideal employee' is driven by the expectation that the soft skills essential for customer service are understood as innate, 'durable and transposable dispositions (...) integrating all past experiences (...)' (Bourdieu, 1977:261) so that candidates have a 'natural ability' to empathise, interact, and inherently understand customers in frontline contexts. Conversations with managers and observation of various interactions reveal a 'social and moral' (Sayer, 2006) devaluation, assuming a correlation between peoples' abilities, class and capacity to learn (Bourdieu, 1984; Sayer, 2005).

Nevertheless, there are distinct differences in approaches to recruitment and selection of frontline service employees across the four hotels. The policies designed and implemented, and how management enact them, play a role in breaking or perpetuating cycles of exclusion and disadvantage and in promoting success in hotels. Though all line managers across the four hotels express a preference for word-of-mouth and referral to attract candidates, Barra and Islay's managers explicitly set out to avoid introducing alien 'modes of comportment' into their hotels (Bourdieu, 1984; Charlesworth, 2000). Management's expectations of employees are fluid and informal but the boundaries within which creativity and individuality are expressed emerge as bounded. Particularly for Barra managers, an inability to step out of 
their comfort zone creates strong exclusionary dynamics so that the intergenerational transmission of advantage and disadvantage' (Sayer, 2009:11) continues as opportunities are rarely offered to those who do not possess the dispositions that inform the perception of an ‘ideal’ employee (Bourdieu, 1984; Sayer, 2005).

Skye is conservative in recruitment and selection with the formal involvement of HR being far more prominent than in Barra. Nevertheless, managers at Skye are open to recruiting from a wider pool of applicants with diverse social and cultural capital backgrounds (Bourdieu, 1977). Though Skye employs university students, they also recruit employees with little or no formal qualifications, as does Mull. Skye and Mull's commitment to equality looks beyond the 'blink' moment of recruitment (Gatta, 2011). Most importantly, the managers display an appreciation of the inclusion and exclusion power via an exclusive focus on the interplay of social, economic and cultural capital and the way it produces social and economic inequalities (Sayer, 2005). Behind this practice is the view that new recruits are not expected to embody a priori a homogenous set of skills and demeanours that will support their ability to provide quality service (Bourdieu, 1977).

Due to the focus on candidates from local colleges and those who have little postschool educational experience, Mull recruits a heterogeneous pool of candidates with different social, cultural and economic backgrounds into casual, part-time and full-time positions. For Skye and Mull there is a moral obligation to widen the net when recruiting. Nonetheless, Mull clearly differentiates between soft and technical skills, displaying a willingness to 'to take a risk' on those candidates who lack knowledge of the industry and the material aspects of serving customers. A strong focus remains on recruiting for 'character', albeit with recognition that to 'serve' is not necessarily an innate capacity. Underlying the approach at Skye and Mull is management's belief that candidates possess the capacity to learn social skills and engage with others in a way that is not determined by their social, 
cultural or economic class (Sayer, 2011). Hence, whilst recruitment decisions are influenced by assumptions about bodily and cultural dispositions that new recruits need to embody, the managers across the two hotels recognize the value of diversity in applicant dispositions through their own reflective-evaluative judgements (Sayer, 2005). Most importantly, the managers display an appreciation of inclusion and exclusion dynamics via social and economic class and, thereby, how class is embodied (Sayer, 2005).

The difference in approach may be explained by the career history of the managers in Skye and Mull. Indeed, managers in both hotels refer frequently to having worked their way up the hierarchy from lower level frontline service roles and display genuine appreciation of the opportunities they were shown, given their own lack of formal qualifications. Managers may place importance on how potential employees present themselves at the interview, but the hotel also creates formal boundaries around grooming and presentation that do not take for granted a common acceptance, as at Barra and Islay hotels. Skye, in particular, is paternalistic in its approach, offering firm guidance on appearance and the shape of the service encounter. They view investment in formal training for a different presentation of self as an investment in human capital (Sayer, 2005). Skye's generally careful design of recruitment, selection and training policy offers transparent regulation that brings opportunities to see where the boundaries of exclusion and inclusion lie. Mull, though more ad-hoc in its adherence to policy, displays a reflective approach to the selection of employees and a willingness to invest in mentoring and training. The exposure to different social fields in their life-course means that Skye and Mull managers develop concerns and needs that reach beyond their current habitat and the prevailing dispositions in the social field. The experience of having worked in lower service positions 'from being a wee girl' enables a questioning of the dominant assumptions that only applicants from privileged backgrounds can fulfil the demand of the ideal employee. This is encoded in their deliberation about the 
exclusionary dynamics an exclusive recruitment of university applicants would create, for example, and the important role that formal training and policy can play in supporting the professional development of candidates from a range of backgrounds.

\section{Conclusion}

By applying Bourdieu's concepts of social class and habitus in tandem with Sayer's theory of class and morality, an exploration of the underlying social mechanisms of recruitment in the hotel sector and employers' perceptions of the 'ideal' worker is offered. The framework reveals how the construction of soft skills, together with potentially exclusionary enactment of recruitment practices, are shaped and reshaped by the dynamics of social class and habitus. Thus, we argue that managers play a significant role in addressing and entrenching social and economic inequality through recruitment, selection and taken-forgranted understandings of soft skills in frontline service work.

In this way, we offer a conceptual contribution that illuminates the class based subtleties in the enactment of recruitment and selection policy as managers confront embodied capacities that are carried as a social identifier, which opens or block pathways to opportunity and prosperity (Sayer, 2005). Yet just as they are learned through interaction, if people are allowed to enter other spaces and receive recognition and esteem, then new capacities can be learned (Archer, 2007; Sayer, 2005) and capitals (economic, symbolic, cultural and social) expanded (Bourdieu, 1984). However, this is not a linear process and it is fraught with obstacles in how such spaces can be accessed.

Clearly four cases from a sub-sector of the hospitality industry in one city cannot claim to offer generalizable knowledge about class based dynamics in recruitment and selection practices across the service sector. However, the study reveals the importance of establishing policies that are commonly enacted by managers committed to key values. We 
say 'potentially' because of the limited data from four hotels, but argue that the focus on people as evaluative beings opens doors to extend the empirical analysis and further investigate the role of line managers in creating and enacting policy across all front-line service sector employment. Retail, for example, holds a growing reputation for its understanding of the ideal employee as displaying a middle-class oral and visual aesthetic (Nickson et al., 2005; 2012; Warhurst and Nickson, 2007). In addition, whilst the study is based in Scotland, Glasgow is a European city which accounts (along with Edinburgh) for the fourth largest growth in hospitality jobs in the UK (Oxford Economics, 2015). The hotels are also part of global chains that share experiences, best practice, training and development across groups. Nevertheless, in revealing the agency of front line service managers, we argue that their influence on the success and growth of the sector is under-played and that a larger focus should be on their development and closer involvement in defining key strategic priorities.

\section{Table 1. Four hotels compared}

\begin{tabular}{|l|l|l|}
\hline Criterion/Hotel & SKYE & BARRA \\
\hline $\begin{array}{l}\text { Recruitment and } \\
\text { selection - Front } \\
\text { line service } \\
\text { employees. }\end{array}$ & $\begin{array}{l}\text { HR drives recruitment \& selection } \\
\text { process strategy. Line managers } \\
\text { involved in process }\end{array}$ & $\begin{array}{l}\text { HR Function responsible for } \\
\text { recruitment. Line Management } \\
\text { involved at every stage }\end{array}$ \\
$\begin{array}{l}\text { Advertise in trade magazine, hotel } \\
\text { website, employment websites, }\end{array}$ & $\begin{array}{l}\text { JobCentre Plus } \\
\text { Basic advertising methods with } \\
\text { strong emphasis on word of mouth } \\
\text { \& social media }\end{array}$ \\
$\begin{array}{l}\text { Procedure is an online survey/ } \\
\text { application; successful candidates } \\
\text { invited to interview }\end{array}$ & $\begin{array}{l}\text { CV s submitted online or accepted } \\
\text { at hotel reception }\end{array}$ \\
$\begin{array}{l}\text { Interview behaviourally focused } \\
\text { and formal i.e. panel interviews } \\
\text { used frequently }\end{array}$ & $\begin{array}{l}\text { Interview informal and situation } \\
\text { focused }\end{array}$ \\
$\begin{array}{l}\text { Hired/promoted supervisors are } \\
\text { trained in interview skills \& }\end{array}$ & $\begin{array}{l}\text { Company policy that two people } \\
\text { clear process for writing-up }\end{array}$ \\
\hline
\end{tabular}




\begin{tabular}{|c|c|c|}
\hline & technique & \\
\hline $\begin{array}{l}\text { Staff } \\
\text { demographics }\end{array}$ & $\begin{array}{l}\text { Statistics not given though staff } \\
\text { remark that employees are largely } \\
\text { female, aged } 18-30 \text {, British \& } \\
\text { Polish employees }\end{array}$ & $\begin{array}{l}\text { Statistics not given though staff } \\
\text { remark that employees are largely } \\
\text { younger, even male and female } \\
\text { split and few older workers }\end{array}$ \\
\hline $\begin{array}{l}\text { Training and } \\
\text { development }\end{array}$ & $\begin{array}{l}\text { Extensive orientation programme } \\
\text { for all new employees } \\
\text { Strong emphasis on people } \\
\text { development \& employment } \\
\text { mobility } \\
\text { Active player in local tourism } \\
\text { training programmes } \\
\text { Rage of employee benefits } \\
\text { Every day the key functions in the } \\
\text { hotel have fifteen-minute training } \\
\text { sessions on particular topics } \\
\text { Employees (primarily supervisors } \\
\text { and above) can apply for } \\
\text { sponsorship for university } \\
\text { qualifications like MBA programs }\end{array}$ & $\begin{array}{l}\text { Orientation programme for all new } \\
\text { employees } \\
\text { Emphasis on people development } \\
\text { with strong economic imperative } \\
\text { Active player in local tourism } \\
\text { training programmes } \\
\text { Range of employee benefits } \\
\text { Training programme available but } \\
\text { ad-hoc }\end{array}$ \\
\hline $\begin{array}{l}\text { Diversity and } \\
\text { Equality } \\
\text { management }\end{array}$ & $\begin{array}{l}\text { Strong relationship with local } \\
\text { council on diversity issues and staff } \\
\text { chair local diversity coalition } \\
\text { Offer work placements to long } \\
\text { term unemployed, former } \\
\text { offenders, \& people recovering } \\
\text { from alcohol and substance misuse } \\
\text { issues }\end{array}$ & $\begin{array}{l}\text { Diversity objectives include } \\
\text { strategic partnerships, targeted } \\
\text { recruitment campaigns, leadership } \\
\text { development programmes, } \\
\text { diversity communications, } \\
\text { conferences \& outreach to women } \\
\& \text { minorities }\end{array}$ \\
\hline Accolades & $\begin{array}{l}\text { Locally recognised for efforts } \\
\text { towards improving diversity } \\
\text { Received award from **** Union } \\
\text { for supported employment \& } \\
\text { recruitment diversity } \\
\text { Received national award for quality } \\
\text { of recruitment and employment }\end{array}$ & $\begin{array}{l}\text { Has won a range for design of the } \\
\text { building } \\
\text { Named Glasgow Hotel of the Year } \\
\& \text { won Customer Care: Hotel of the } \\
\text { year }\end{array}$ \\
\hline Criterion/Hotel & MULL & ISLAY \\
\hline $\begin{array}{l}\text { Recruitment and } \\
\text { selection - Front } \\
\text { line service } \\
\text { employees. }\end{array}$ & $\begin{array}{l}\text { Interview: competency-based } \\
\text { framework } \\
2 \text { interviews, references sourced } \\
\text { before offer goes out }\end{array}$ & $\begin{array}{l}\text { Careers website called Taleo. It can } \\
\text { specify certain parameters (i.e. can } \\
\text { work weekends) }\end{array}$ \\
\hline
\end{tabular}




\begin{tabular}{|c|c|c|}
\hline & $\begin{array}{l}\text { CVs: if job requires technical skill, } \\
\text { then technical skill (food hygiene } \\
\text { certificate, knowledge of a certain } \\
\text { process in the business) would } \\
\text { come first on shortlist } \\
\text { The use of TalentSelect system } \\
\text { (craft, HOD and executive) } \\
\text { Organisation uses Caterer, } \\
\text { LinkedIn, S1 Jobs, Gumtree, } \\
\text { Jobcentre and, depending on role, } \\
\text { level of contract, word-of-mouth to } \\
\text { recruit }\end{array}$ & $\begin{array}{l}\text { First interview often with just a } \\
\text { recruitment officer, or sometimes } \\
\text { with the head of department, and } \\
\text { senior manager (such as the GM or } \\
\text { deputy GM) will do second } \\
\text { interview (Glasgow) } \\
\text { Questions are competency based } \\
\text { and focus on quality, productivity, } \\
\text { adaptability, teamwork, customer } \\
\text { focus and dependability } \\
\text { GM or Deputy GM meet every } \\
\text { guest-facing employee at least once } \\
\text { before they are employed } \\
\text { (Glasgow) } \\
2 \text { Interviews (minimum), possibly a } \\
\text { trial shift. Upon employment, } \\
\text { induction }\end{array}$ \\
\hline $\begin{array}{l}\text { Staff } \\
\text { demographics }\end{array}$ & $\begin{array}{l}\text { 115FT, casuals vary depending on } \\
\text { season } \\
\text { Events department: } 6 \mathrm{FT}, 54 \text { Zero } \\
\text { Hours }\end{array}$ & $\begin{array}{l}\text { 150/160 employees, of which } \\
\text { approx. } 40 \% \text { are full-time } \\
\text { Reception and Housekeeping are } \\
\text { primarily contracted staff, others } \\
\text { consist of zero hour staff and } \\
\text { management }\end{array}$ \\
\hline $\begin{array}{l}\text { Training and } \\
\text { development }\end{array}$ & $\begin{array}{l}\text { Staff are offered a range of training } \\
\text { courses to enhance their skills, and } \\
\text { also on systems and language skills }\end{array}$ & $\begin{array}{l}\text { Every department has a trainer. The } \\
\text { hotel do a full induction which } \\
\text { includes brand orientation, health } \\
\text { and safety, and allows staff access } \\
\text { to } * * * * \text { Worldwide University with } \\
\text { over } 7000 \text { courses available } \\
\text { (management have direct access to } \\
\text { it) }\end{array}$ \\
\hline $\begin{array}{l}\text { Diversity and } \\
\text { Equality } \\
\text { management }\end{array}$ & $\begin{array}{l}\text { Formal reference in documentation } \\
\text { only }\end{array}$ & $\begin{array}{l}\text { Formal reference in documentation } \\
\text { only }\end{array}$ \\
\hline Accolades & $\begin{array}{l}\text { Strongly aligned with City of } \\
\text { Glasgow College, Glasgow } \\
\text { schools, Prince's Trust }\end{array}$ & $\begin{array}{l}\text { Scottish Executive Chef of the } \\
\text { Year (recent) } \\
\text { The people awards (gold laurel) }\end{array}$ \\
\hline
\end{tabular}

\section{References}

Archer M (2007) Making Our Way Through the World: Human Reflexivity and Social Mobility. Cambridge: Cambridge University Press.

Baum T (2002) Skills and Training for the Hospitality Sector: A Review of Issues. Journal of Vocational Education and Training, 54:3, 343-364.

Beck U (1992) Risk Society: Towards a New Modernity. London: SAGE. 
Bolton S (2004) Conceptual Confusions: Emotion Work as Skilled Work. In C. Warhurst, E. Keep and I. Grugulis (Eds.), The Skills that Matter. London: Palgrave Macmillan.

Bourdieu, P (1977) Outline of a Theory of Practice, 16,Cambridge university press.

Bourdieu P (1984) Distinction. London: Routledge.

Bourdieu, P (1986) The forms of capital, Cultural theory: An anthology, 1,81-93.

Bourdieu P (1990) The logic of practice. Stanford California: Stanford University Press.

Braun V Clarke V (2006) Using thematic analysis in psychology. Qualitative Research in Psychology 3(2), 77-101.

Bryant L Jaworski K (2011) Gender, embodiment and place: The gendering of skills shortages in the Australian mining and food and beverage processing industries. Human Relations, 64(10): 1345-1367.

Bryson J (2017) The Disciplinary Perspectives on Skill, in: Warhurst, C Mayhew, K Finegold, D Buchanan J (2017) eds. The Oxford Handbook of Skills and Training. Oxford University Press.

Callaghan G Thompson P (2002) We recruit for attitude. Journal of Management Studies, $39(2), 233-254$.

CEDEFOP (2014) Skill mismatch: more than meets the eye. Available from: http://www.cedefop.europa.eu/de/publications-and-resources/publications/908.

CEDEFOP (2015) Skill shortages and gaps in European enterprises: striking a balance between vocational education and training and the labour market. Luxembourg: Publications Office.

Charlesworth SJ (2000) A phenomenology of working class experience. Cambridge: Cambridge University Press.

De Roeck, K Maon, F and Lejeune, C (2013) Taking up the challenge of corporate branding: an integrative framework. European Management Review, 10,(3),137-151.

Devine F (2004) Class Practices. Cambridge: Cambridge University Press.

Devine F (2010) Habitus and classifications. In: Silva E and Warde A (eds) Cultural Analysis and Bourdieu's Legacy. London: Routledge.

Emirbayer, Mustafa, and Ann Mische (1998) "What is Agency?" American Journal of Sociology, 103, 962-1023.

European Commission (2015) Employment and Social Developments in Europe 2015, Directorate-General for Employment, Social Affairs and Inclusion.

Eustace, E (2012) 'Speaking allowed? Workplace regulation or regional dialect'. Work, Employment and Society, 26, (2), 331-348.

Gallie D, Felstead A, Green F and Inanc H (2016) 'The hidden face of job insecurity'. Work, employment and society, online first. 
Gatta M (2011) In the 'Blink' of an Eye-American High-End small Retail Businesses and the Public Workforce System. In O. Bozkurt and I. Grugulis (Eds.), Retail Work. Basingstoke: Palgrave Macmillan.

Goldthorpe JH Mills C (2008) Trends in intergenerational class mobility in modern Britain: Evidence from national surveys, 1972-2005. National Institute Economic Review:205: 83-100.

Gomez, ML (2010) A Bourdieusian perspective on strategizing. Cambridge handbook of strategy as practice, 141-154.

Grugulis, I Warhurst C and Keep E (Eds.) (2004) What's Happening to 'Skill'? London: Palgrave.

Hampson I Junor A (2010) Putting the process back in: rethinking service sector skill. Work, Employment and Society, 24, 526-545.

Hurrell SA Scholarios D and Thompson P (2013) More than a 'humpty dumpty' term: Strengthening the conceptualization of soft skills. Economic and Industrial Democracy, 34 (1), 161-182.

Hurrell SA (2016) Rethinking the soft skills deficit blame game: Employers, skills withdrawal and the reporting of soft skills gaps. Human Relations, 69, (3), 605-628.

Hurrell SA Scholarios D (2014). The people make the brand: Reducing social skills gaps through person-brand fit and human resource management practices. Journal of Service Research', 17 (1), 54-67.

Karatas-Ozkan M Chell E (2015) Gender Inequalities in Academic Innovation and Enterprise: A Bourdieuan Analysis. British Journal of Management, 26, 109-125.

Knox, A Walsh, J (2005) Organisational flexibility and HRM in the hotel industry: evidence from Australia. Human Resource Management Journal, 15(1), 57-75.

Korczynski M (2005) Skills in service work: An overview. Human Resource Management Journal 15:2, 3-14.

Lamont M (2000) The Dignity of Working Men: Morality and the Boundaries of Race, Class and Imagination. New York: Russell Sage Foundation and Harvard University Press.

Lockyer C Scholarios D (2004) 'Selecting Hotel Staff: Why Best Practice does not Always Work'. International Journal of Contemporary Hospitality Management, 16 (2), 125 135.

Macdonald C and Merrill D (2009) Intersectionality in the Emotional Proletariat, A New Lens on Employment Discrimination in Service Work. In M. Korczynski and C. Macdonald (Eds.), Service Work- Critical Perspectives. New York: Routledge.

Maxwell GA Watson S (2006) Perspectives on line managers in human resource management: Hilton International's UK hotels. The International Journal of Human Resource Management, 17 (6), 1152-1170. 
McDowell L (2009) Working Bodies. Chichester: John Wiley and Son.

McDowell L Batnitzky A and Dyer S (2007) 'Division, segmentation, and interpellation: the embodied labors of migrant workers in a Greater London hotel'. Economic Geography, 83:1, 1-25.

McGovern P Hill S Mills C and White M (2007) Market, Class and Employment.Oxford: Oxford University Press.

Mouzelis N (1995) Sociological theory: what went wrong? Diagnosis and remedies. London: Routledge.

Moss P and Tilly C (1996) 'Soft' skills and race: An investigation of black men's employment problems. Work and Occupations, 23, (3): 252(3).

Nieves, J (2016) Outcomes of Management Innovation: An Empirical Analysis in the Services Industry. European Management Review, (13), 125-136.

Nickson D (2013) Human Resource Management for Hospitality, Tourism and Events. New York: Routledge.

Nickson D Warhurst C and Dutton E (2005) The importance of attitude and appearance in the service encounter in retail and hospitality. Managing Service Quality, 15: 2,195 - 208.

Nickson D Warhurst C Cullen AM Watt A (2003) Bringing in the Excluded? Aesthetic labour, skills and training in the 'new' economy, Journal of Education and Work, 16, 2.

Nickson D Warhurst C Commander J Hurrell S and Cullen A M (2012) Soft skills and employability: Evidence from UK retail. Economic and Industrial Democracy, 33 (1), 65-84.

Nickson D Price R Baxter-Reid Hurrell S (2016) Skill requirements in retail work: the case of high-end fashion retailing. Work, employment and society, 31(4) 692-708.

Oxford Economics (2015) Economic contribution of the UK hospitality industry. Source: http://www.bha.org.uk/wordpress/wp-content/uploads/2015/09/Economiccontribution-of-the-UK-hospitality-industry.pdf. Accessed on the 29/09/2016.

Pakulski J and Waters M (1996) The Death of Class. London: Sage.

Price L (1993) The limitations of the law in influencing employment practices in UK hotels and restaurants. Employee Relations, 15:2, 16-24.

Savage M Devine F Cunningham N Taylor M Li Y and Hjellbrekke J (2013) A new model of social class? findings from the BBC's great British class survey experiment. Sociology 47 (2), 219-250.

Sayer A (1995) Radical political economy. Oxford: Blackwell. 
Sayer A (2005) The moral significance of class: Cambridge University Press.

Sayer A (2011) Why Things Matter to People: Social Science, Values and Ethical Life. Cambridge: Cambridge University Press.

Sherman R (2007) Class Acts: Service and Inequality in Luxury Hotels. Berkeley and Los Angeles: University of California Press.

Skeggs B (2004) Class, Self, Culture. London: Routledge.

Skills Development Scotland (2016) Skills Assessment January 2016. Available from: https://www.skillsdevelopmentscotland.co.uk/media/40981/glasgow.pdf Last accessed on 30/05/2016.

Standing, G (2014) A precariat charter: From denizens to citizens. A\&C Black.

Sozen, HC Varoglu, D Yeloglu, HO and Basim, HN (2015) Human or Social Resources Management: Which Conditions Force HR Departments to Select the Right Employees for Organizational Social Capital?. European Management Review, (13), 3-18).

UK Commission for Employment and Skills (UKCES) (2014) UK Commission's Employer Skills Survey 2013: UK Results. Wath-upon-Dearne: UKCES.

UK Commission for Employment and Skills UKCES (2016) Employer Skills Survey 2016. Available from: https://www.gov.uk/government/uploads/system/uploads/attachment_data/file/525444 /UKCESS_2015_Report_for_web_May_.pdf. Last accessed on 28/05/2016.

Vincent S (2011) The emotional labour process: An essay on the economy of feelings. Human Relations, 64(10), 1369-1392.

Warhurst C Nickson D (2007) Employee experience of aesthetic labour in retail and hospitality, Work, Employment and Society, 21:1: 103-120.

Warhurst C Nickson D (2007) A new labour aristocracy? Aesthetic labour and routine interactive service, Work, Employment and Society, 21(4): 785-798.

Wolkowitz, C (2006) Bodies at Work, London: Sage. 